by A. Schallamach) has been developed in terms of the number and average life-time of the bonds due to molecular adhesion being dependent on the velocity and temperature of the rubbing members. The enhanced strength properties of reinforced rubbers are shown to result from the effects of rubber hysteresis in reducing the stress at the tip of the growing crack (Publication No. 475, by E. H. Andrews), and the effect of filler particles is illustrated by electron microscope photographs. The deformation properties of foamed elastic materials are discussed (Publication No. 478, by A. N. Gent and A. G. Thomas) in terms of a modol consisting of a three. dimensional network of thin threads. The theory is extended to open-cell foams by considering the viscous damping due to the flow of air through such a network.

\section{Mineral Deficiencies in Rubber Cultivation}

AGRICULTURAI. science owes much to an undorstanding of signs displayed by the plants themselves and by the leaves in particular. In tho sphere of rubber cultivation, as in so many others, painstaking pot culture and field experimentation have been rewarded by a knowledge of the mineral shortages linked with given leaf symptoms. A recently published monograph from Kynoch Press, entitled Mineral Deficiencies in Hevea and Associated Cover Plants, contains excellent reproductions, from colour photographs, of leaves affected by deficiencies of the essential major and minor nutrient elements (By Victor M. Shorrocks. Pp. viii +76 (53 plates). Kuala Lumpur: Rubber Research Institute of Malaya, 1964. 25 Malayan dollars). Research on the soil, that "frugal custodian of plant nutrients", to quote the author's own description. has been prosecuted by the Rubber Research Institute of Malaya since the late 1920's, and this publication, nourished on earlier work which rosulted in the compilation of Bolle-Jones, shows a healthy response indeed. Alongside symptoms found in Hevea brasiliensis are set those in three commonly found leguminous ground cover plants, Pueraria phaseoloides, Centrosema pubescens and Calopogonium mucunoides, thus enabling the grower to turn these species to a now advantage as 'indicator' plants. Descriptions of deficiency symptoms and of their occurrence, not overlooking waterlogging symptoms, albeit strictly applicable to Malaysian conditions only, will be of value to workers in many other rubber-growing areas, as will the introductory section on plant nutrients to those studying different crops. Tables of published data are given on the results of leaf analysis, a tochnique which the author himself has used to no mean effect. To achieve successful corrective fertilizer application it will surely bo essential to follow the advice given here. At the present time, known deficiencies in Malayan rubber trees include magnesium, potassium, calcium, nitrogen, phosphorus and manganose. We may look forward to progress, say, on such topics as yiolds and their relation to minor elements, and this timely publication marks an important stage in a field having world-wide economic implications.

\section{Laminated Timber Structures}

Modern gluing techniques have rondered possible the use of laminated wood in timbor structures of almost any size and shape. This form of construction is now appar. ently finding favour with architects concerned with certain types of building such as churches, schools, recreation halls, social centres, restaurants and, whore practicable, industrial buildings. Laminated timber permits of combined structural strength and attractive design. Glued timber structures are free from corrosion hazards; thus maintenance costs are greatly reduced or even eliminated. A recent issue of Technical Notes 258 (CIBA (A.R.L.), Ltd., Duxford, Cambridge, June 1964) is devoted entirely to "Timber Structures by Muirhead and Sons, Ltd." Details and illustrations of several examples of laminated work incorporating 'Aerodux' resorcinol adhesive (made and supplied by CIBA) are given. These include a frame- work for a sports building at Newcastle upon Tyne, circular in shape, with an overall diameter of $206 \mathrm{ft}$; a sports hall at Grangemouth with laminated timber portal frames spanning $35 \mathrm{ft}$.; the Church of the Holy Rood, Grangemouth, with laminated gothic arches with a span of $45 \mathrm{ft}$.; showrooms for the South of Scotland Electricity Board at Airdrie, in which very extensive use was made of laminated timber work incorporating 'Aerodux 185' adhesive; a cattle court in East Lothian having laminated portal frames spanning about $60 \mathrm{ft}$. The applications of laminated woodwork structures as described in this pamphlet are certainly impressive, but whether in the long run this type of timber construction ". . . is able to offer serious competition with steel and reinforced concrete", for examplo in tho tower-block typo of buildings now so conspicuous in London and elsewhere, likewise in modern school and factory designs, must, for many obvious reasons, remain a moot point.

\section{Architecture of the Oviduct of the Domestic Hen}

IN response to the article with the above title, which appeared on p. 699 of the August 15 issue of Nature, Prof. G. M. Wyburn has written to the Editor, pointing out that probably the most comprohensive histological investigation of the hen oviduct was carried out by Dr. $K$. Richardson in 1935. The work was undertaken in the Anatomy Department, University College, London, when Dr. Richardson was investigating the secretory phenomena in the oviduct of the fowl, including the process of shell formation, by means of the micro-incineration technique (Phil. Trans., B, 225, 149; 1935). These investigations have recently been extended by electron microscope surveys in the Anatomy Department of the University of Glasgow. One of these, by Drs. R. M. C. Aitken and H. S. Johnston, was concerned with the fine structure of the infundibulum of the avian duct ( $J$. Anat. London, 97 ; 1963). It showed that cells of the infundibular glands differ in certain respects from those of the succeoding albumen-secreting region and may bo of greater significance in chalaza production than heretofore supposed and not simply additional albumon-secreting glands; although it is probable that these represent particular functional states of the same cell, this has not yet been confirmed. Ciliated non-secretory, ciliate secretory and non-ciliated secretory cells were distinguished in the surface epithelium, and the possibility of transformation from one type to another was suggested. Tho cilia present distinctivo features, the apparent cross-striation of the rootlet in this species being due to its ensheathment by a fibro arranged as a helix. The structure is therefore reminiscent of the spermatoroon. Further investigations have boen made by Drs. Johnston and Aitken and Prof. G. M. Wyburn into the fine structure of the avian uterus (J. Anat. London, 97, 3; 1963). This has revealed that the apical and basal cells show marked differences in their fine structuro. Their significance in relation to the formation of the shell matrix and cuticle was also examined. The distinctive features of the junctional zone glinds of the uterus were described, including the types of secretory granule. The uterine gland cells have secretory granules within vacuoles, and changes in the microvilli of these cells are possibly related to the passage of calcium ions during calcification of the organic matrix of the shell. Two types of dense cytoplasmic body have beon demonstrated in the cytoplasm of the uterine gland cell. There is some evidence to support the viow that the granular bodies, which may be lysosomes, are derived from mitochondria.

\section{Spectrochemical Analysis of Soils, Plants and Related} Materials

IT is about forty years since attention was first directed to the importance of minute amounts of certain elements in the healthy growth of plants and animals. Boron and then manganese and cobalt, followed by copper, zinc and 